\title{
Retrospective ANALYSIS OF SySTEMATIC LAND-COVER ChANGE IN THE UPPER WESTERN BUg RIVER CATCHMENT, UKRAINE
}

\author{
Cornelia Burmeister ${ }^{1}$ Jochen Schanze ${ }^{2}$ \\ ${ }^{1}$ Technische Universität Dresden (TUD), International Institute Zittau, \\ Chair of Ecological and Revitalizing Urban Transformation, \\ 01062 Dresden, Germany \\ ${ }^{2}$ Technische Universität Dresden (TUD), Faculty of Environmental Sciences, \\ Chair of Environmental Development and Risk Management, \\ 01062 Dresden, Germany \\ ${ }^{2}$ Leibniz Institute of Ecological Urban and Regional Development (IOER), \\ 01217 Dresden, Germany \\ e-mail: ${ }^{1}$ cornelia.burmeister@tu-dresden.de; ${ }^{2}$ jochen.schanze@tu-dresden.de
}

\begin{abstract}
The paper presents the approach and empirical findings of a study on systematic land-cover change in the upper Western Bug River catchment in Ukraine. Landsat and SPOT images as remote sensing data are used for land-cover classification for the time steps 1989, 2000 and 2010. Thereby, three inner-annual scenes represent the vegetation development for each time step and facilitate classification with the Maximum Likelihood Classifier. Six classes are detected: artificial surface, broad-leaved and coniferous forests, arable land, grassland and water bodies. After this step, land-cover change detection over two decades is conducted. The observed against the expected gross loss and gross gain are statistically analyzed to identify the systematic and random land-cover changes in the study region. Results show that arable land changes not into artificial surface. Arable land changes into grassland and vice versa. This systematic change is very strong. The forest classes interchange whereat broad-leaved forest gains more from coniferous forest in the last decade.
\end{abstract}

\section{Keywords}

Land cover; Systematic land-cover change; Western Bug River; Ukraine.

\section{Introduction}

When a comprehensive terrestrial database is lacking, remote sensing data as satellite images or aerial photographs from different dates may visualize changes in land-cover (LC) and to a certain extent in land use (LU). LC is commonly understood as the biophysical condition of the earth surface [1, 2, 3], including e.g. bare soil, vegetation or crops and man-made constructions covering the surface like buildings or infrastructure. It comprises everything that is directly detectable by earth observation on the ground or via remote sensing data. Besides, LU is often defined as human activities exploiting and utilizing the land for a certain purpose $[1,2,3]$. Typical examples are nature protection, recreational and commercial areas. Since LU is not directly visible via observation methods, additional information such as socio-economic data, statistics, or particular field surveys are needed [2, 3].

Change may refer to LC, to LU or to both. Geist et al. [3] differentiate LC change into conversion or modification. The former occurs when one LC type is substituted by another one and is easily detectable. The latter is distinguished by the gradual change of the character of a LC class and the change is hardly visible [3]. 
Various techniques of remote sensing and GIS allow LC/LU change to be quantified, e.g. when LC/LU maps from different time steps are compared with each other. The product of the comparison is mostly a transition matrix, which presents the change of one LC category to another. This two-dimensional table fails to show all information, like e.g. the relevant changes $[4,5]$ or the existence of multiple possibilities of land-cover transitions [6]. Braimoh [7] introduced a method to differentiate between random and systematic (categorical) change by enhancing this transition matrix. They understand random transitions as a change that occurs once between two time steps because of abrupt changes, whereas a systematic change is recognized as a transition that is recurrent due to regular or common processes of change.

In this article, the systematic LC change detection is shown for the Upper Western Bug River catchment in Ukraine which was one of the tasks of a more comprehensive integrated water resource management (IWRM) study [8]. LC change in addition to climate change served as a driver for modelling a long-term change of the water and matter balance $[9,10,11]$.

The research presented in this article consists of the following steps: (i) generation of comprehensive land-cover maps for the years 1990, 2000 and 2010 based on the classification of satellite data for urban, arable and forest land-cover classes; (ii) change detection for these land-cover maps with contingency tables to show LC change; and (iii) enhanced statistical analysis to depict systematic LC change.

\section{$1 \quad$ Study Region}

The upper part of the Western Bug River catchment is situated in the west of Ukraine, with its spring in the Podolian Highlands as can be seen in Fig. 1, Maps A to D. Thereby, map A shows the rivers and main towns of the study region. Map B presents the whole Western Bug River catchment. Map C covers the delineation of the study area within the administrational Oblast units and Map D depicts the study area within the administrational Rayon units. The river flows via Belarus to Poland and leads to the Narew River. The latter then flows into the Vistula River which ends in the Baltic Sea (see Fig. 1, Map B).

The study region is around 2,550 $\mathrm{km}^{2}$ large [8] and reaches to the gauge of Dobrotvir in the North (see Fig. 1, Maps A, C and D). The western upper part is strongly influenced by the regional capital Lviv with about 734,000 inhabitants (year 2010, [12]). There, the Western Bug tributary Poltva River has its spring (see Fig. 1, Map A). The Poltva is determined by the discharge of the wastewater treatment plant of Lviv and various industries which lower the water quality of the tributary tremendously [13]. Other important cities of the catchment area are Zolochiv in the South, Buzk and Kamianka Buzka (see Fig. 1, Map A). The investigated catchment is characterized by agricultural activities and dense settlement structures in the rural areas [9].

The study region lies completely in Ukraine as a post-Soviet country which gained its independence in 1991. In Soviet times the state was characterized by rich natural resources, a highly qualified population and intensive agricultural production. With the change of the political and economic system from communism towards capitalism, a rapid societal and demographic change took place [14-16]. The population is shrinking because of low birth rates, high death rates due to diseases like cardiovascular diseases [14], and poverty caused by high unemployment rates and broad migration of workers into the EU or Russia. Gorobets [17] states that after getting independence Ukraine failed to ensure a successful transition and sustainable development mainly due to inefficient economic structures which are still resource intensive and the usage of old technology which pollutes the environment. Moreover, limited functioning of institutions, not only for environmental management and education is visible, but also a weak decision-making is present. There is still no functioning land-market to buy 
and sell land because of the fear of "outselling" the land $[18,19]$. Today, Ukraine has been in political struggles with separatists since 2014, which lowers the living conditions and planning reliability.

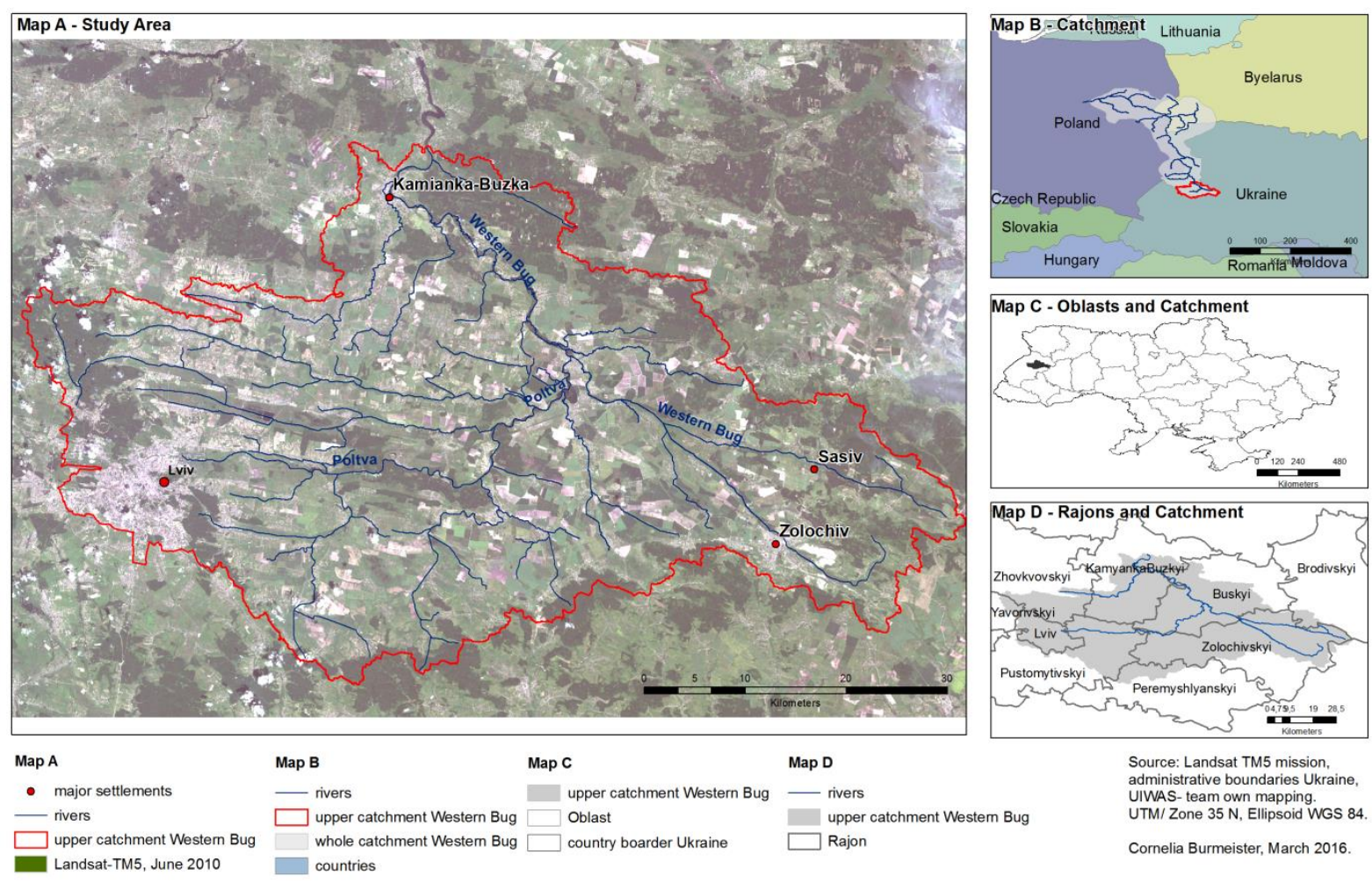

Source: Own calculation, see lower right corner of Fig. 1.

Fig. 1: Study region with the upper Western Bug River catchment

\section{$2 \quad$ Methods and Data}

\subsection{Data and Pre-processing}

Satellite scenes from Landsat (WRS 186/26) and SPOT are used to derive reliable LC maps via classification with the necessary scale for subsequent parameterization of the water and matter balance models $[10,11]$. The Landsat and SPOT platforms are chosen because they provide a continuity over a long time horizon [20]. The three time steps 1989, 2000, 2010 (cf. also Tab. 1) are meant to represent the socialist period in 1989, the development after the revolution from 2000 to 2010, and the present state before the struggles with separatists took place. Additionally, this time step was used to model the water and matter balance of the catchment $[10,11]$.

Each time step is represented by three inner-annual scenes covering the beginning, mid and end of the vegetation period (cf. Tab. 1) to distinguish arable land, managed grassland, natural grassland, bare soil on arable land and urban area.

All satellite images are atmospheric corrected, georeferenced (SPOT to Landsat) and pansharpened to 15 x 15 m. Furthermore, the Normalized Difference Vegetation Index (NDVI) is calculated. This is used to differentiate between vegetated areas and sealed surfaces to facilitate classification.

The data for ground truthing are scarce. Topographic maps at the scale of 1:100,000 from the year 1984, and some selected topographic maps with a scale of 1:10,000 for some parts of Lviv and the Sasiv sub-catchment are available. Usability of the latter is very limited since 
they are without any dates of production or actualization. As an additional data source, the GeoEye scenes in Google Earth are used for gaining ground truth data, especially for the time step 2010 (cf. section 2.2). These data are complemented in field campaigns in the years 2009, 2010 and 2012.

\subsection{Classification Process}

A supervised classification is performed with the statistical classifier Maximum Likelihood which assigns the pixel to the class with the highest class probability based on training pixels.

For the Maximum-Likelihood Classifier, training data for the pre-definition of classes are needed. To delineate training samples for each class, ground truth data from the field campaigns are taken. Google Earth is used to complete the data for 2010 where some GeoEye scenes are available for the city of Lviv. The rural part of the catchment is presented in Google Earth with SPOT scenes. The reference data for the time step 1989 are collected with the topographic maps in the scale for 1:100.000 which are available for the whole investigated catchment and 1:10.000 which is available for a sub-catchment (see section 2.1). Additional visual image interpretation of the Landsat and SPOT scenes is done for the derivation of reference data. For the time step 2000 only visual image interpretation of the Landsat and SPOT scenes can be made for the collection of reference data.

These collected ground truth reference points are randomly divided into two parts. One part is used for training samples for the delineation of each LC class and the other part for assessing the accuracy of the classification afterwards.

A post-classification enhancement is undertaken for the LC class AS with a settlement layer which is acquired by editing in different time steps on the satellite images.

\subsection{Change Detection for Differentiation between Random and Systematic Change}

Post-classification change detection is undertaken by calculating the contingency table (transition matrix) from one time step to another, so that class $i$ changes in a percentage rate to class j. An enhanced calculation of indicators, which describes the change in more detail, is carried out with the persistence, gross loss and gross gain, net change, total change, and swap $[4,5,7]$. The persistence is the consistent unchanged percentage of one LC class between two time steps. The gross loss is the total sum of the LC category in time step one minus the persistence. The gross gain is calculated by the total amount of the LC category in the second time step minus the persistence. The net change is calculated by the difference of gross gain and gross loss. In contrast, the total change is derived by addition of the two. Finally, the swap is the difference of the total change and the net change [5] and provides information about the changes (gains and losses) of a LC category on different spatial sites. It presents the real change of a LC class, because the gain and loss of a category do not always take place at the same location, e.g. a loss of a specific LC class can be balanced by a gain of this specific LC class in another place, so the net change would be zero and indicate no change, which of course does not represent the truth [4]. With these numbers no assumptions of systematic change can be derived. Therefore, the assumption is made that the random process of the gross loss and gross gain is set in relation to the class size [5, 7]. If the gross gain or gross loss is not random, it is called a systematic transition (process). A systematic transition occurs when the deviation between the observed gross loss/gross gain minus expected gross loss/gross gain is either negative or positive.

The calculation for the random expected gross gain is in equation $(1)[5,7]$ : 


$$
G_{i j}=\left(p_{+j n}-i_{n} j_{n}\right) \cdot \frac{p_{\text {in+ }}}{100-p_{j n+}} \text { where } i \neq j
$$

$G_{i j}$ is the expected gain within the transition of the category $i$ to the category $j$. The first paragraph expression $\left(p_{+j n}-i_{n} j_{n}\right)$ is the observed gross gain, $p_{i n+}$ is the sum of the row of the category $i$ and $p_{j n+}$ is the sum of the row of category $j$ in the contingency table.

The calculation of the random expected gross loss is in equation (2) [7]:

$$
L_{i j}=\left(p_{i n+}-i_{n} j_{n}\right) \cdot \frac{p_{+j n}}{100-p_{+i n}} \text { where } i \neq j
$$

$L_{i j}$ is the expected loss within the transition of the category $i$ to the category $j$. The first paragraph expression $\left(p_{i n+}-i_{n} j_{n}\right)$ is the observed gross loss, $p_{+j n}$ is the sum of the column for category $j$ and $p_{+i n}$ is the column sum of category $i$ in the contingency table.

Finally, the deviation between observed and expected gross gain has to be interpreted and assessed: a positive deviation between category $i$ and $j$ means that category $i$ is systematically gaining from category $j$; a negative deviation between category $i$ and $j$ impedes systematic gains from category $i$ to category $j$.

The difference of the observed and expected gross loss has to be interpreted too: a positive deviation between category $i$ and $j$ results in the systematic losing from category $i$ to category $j$; a negative balance indicates that category $i$ is losing to category $j$ systematically.

A systematic transition is given, if class $i$ systematically gains from class $j$ and class $j$ systematically loses to class $i$.

\section{$3 \quad$ Results}

\subsection{Classification Results and Land-Cover Change between 1989, 2000, and 2010}

Tab. 1 presents the used satellite images for the classification process. Images with high cloud coverages are rejected.

\begin{tabular}{|c|c|c|c|}
\hline Time step & Data & Satellite sensor & Geometric resolution \\
\hline \multirow[t]{2}{*}{1989} & $\begin{array}{l}1989-07-07 \\
1989-08-16 \\
1993-04-21\end{array}$ & Landsat-TM 5 & $30 \times 30 \mathrm{~m}$ \\
\hline & $\begin{array}{l}1989-07-12 \\
1989-08-18 \\
1989-08-30\end{array}$ & SPOT-1 & $10 \times 10 \mathrm{~m}$ \\
\hline 2000 & $\begin{array}{l}2000-05-02 \\
2000-08-22 \\
2001-04-03\end{array}$ & $\begin{array}{l}\text { Landsat-7 ETM +, } \\
\text { band } 1 \text { to } 5,7 \\
\text { band } 8 \text { (pan) }\end{array}$ & $\begin{array}{l}30 \times 30 \mathrm{~m} \\
15 \times 15 \mathrm{~m}\end{array}$ \\
\hline \multirow[t]{2}{*}{2010} & $\begin{array}{l}2010-04-04 \\
2010-06-07 \\
2010-11-14\end{array}$ & Landsat-TM 5 & $30 \times 30 \mathrm{~m}$ \\
\hline & $\begin{array}{l}2007-08-23 \\
2009-04-19 \\
2009-07-18\end{array}$ & $\begin{array}{l}\text { SPOT-4 } \\
\text { SPOT-2 } \\
\text { SPOT-5 }\end{array}$ & $\begin{array}{l}10 \times 10 \mathrm{~m} \\
10 \times 10 \mathrm{~m} \\
5 \times 5 \mathrm{~m}\end{array}$ \\
\hline
\end{tabular}

Tab. 1: Satellite scenes used for the three time steps

Source: Own 
On the whole, six classes are detected: 'artificial surface' (AS), arable land' (AL), 'broadleaved forest' (BLF), 'coniferous forest' (CF), 'natural grassland' (GL), and 'water bodies' (WB). Additionally, the class 'peat bogs' (PB) is detected for the time step 1989, which disappears in the time step 2000 (cf. Tab 2).

Tab. 2: Classification scheme

\begin{tabular}{|l|l|}
\hline Land-cover class & Description of class and detection \\
\hline artificial surface (AS) & $\begin{array}{l}\text { Settlement, infrastructure such as road etc. and impervious } \\
\text { surface. }\end{array}$ \\
\hline arable land (AL) & $\begin{array}{l}\text { Agricultural area and mowed grassland (managed). It is } \\
\text { detected through the different phenological states using the } \\
\text { inner-annual satellite images representing the vegetation } \\
\text { period. With this procedure it is possible to achieve a high } \\
\text { quality of identification of a single field plot and in } \\
\text { subsequence of this LC class because the farming plots are } \\
\text { vegetated in at least one satellite scene during the vegetation } \\
\text { period. Managed grassland is also subsumed in this LC class, } \\
\text { allowing it to be distinguished from natural grassland. }\end{array}$ \\
\hline $\begin{array}{l}\text { broad-leaved forest (BLF) } \\
\text { coniferous forest (CF) }\end{array}$ & Forest is divided on the basis of different spectral signatures. \\
\hline Natural grassland (GL) & $\begin{array}{l}\text { Vegetation cover through the whole year (unmanaged), with } \\
\text { the three inner-annual scenes. }\end{array}$ \\
\hline peat bogs (PB) & Specific spectral signature of non-vegetated areas. \\
\hline water bodies (WB) & Specific spectral signature. \\
\hline
\end{tabular}

Source: Own.

The classification of the three time steps resulted in the aforementioned $6 \mathrm{LC}$ classes AS, AL, BLF, CF, GL, and WB (cf. section 2.2 and Tab. 3), with the addition of one more LC class in the year 1989: PB.

Tab. 3: Results of land-cover change between 1989, 2000 and 2010

\begin{tabular}{|c|c|c|c|c|c|c|c|c|}
\hline \multicolumn{2}{|c|}{ LC classes } & AS & $\mathrm{AL}$ & BLF & $\mathrm{CF}$ & GL & PB & WB \\
\hline \multirow[t]{3}{*}{$\sum$} & 1989 & 10.7 & 47.2 & 15.0 & 5.1 & 20.6 & 1.2 & 0.1 \\
\hline & 2000 & 11.3 & 47.2 & 17.0 & 4.3 & 19.9 & 0 & 0.3 \\
\hline & 2010 & 13.3 & 44.3 & 13.9 & 4.8 & 23.5 & 0 & 0.3 \\
\hline \multirow[t]{6}{*}{ 1989- } & persistence & 9.2 & 39.0 & 13.7 & 3.2 & 11.5 & 0 & 0.1 \\
\hline & gross gain & 2.1 & 8.2 & 3.4 & 1.1 & 8.4 & 0 & 0.2 \\
\hline & gross loss & 1.5 & 8.2 & 1.4 & 1.9 & 9.1 & 1.2 & 0.0 \\
\hline & net change & 0.6 & 0.0 & 2.0 & 0.9 & 0.7 & 1.2 & 0.2 \\
\hline & total change & 3.6 & 16.4 & 4.7 & 3.0 & 17.5 & 1.2 & 0.2 \\
\hline & swap & 3.0 & 16.4 & 2.7 & 2.1 & 16.8 & 0 & 0.1 \\
\hline \multirow[t]{6}{*}{$2000-$} & persistence & 10.7 & 36.0 & 12.5 & 3.1 & 11.3 & & 0.2 \\
\hline & gross gain & 2.5 & 8.3 & 1.4 & 1.7 & 12.1 & & 0.1 \\
\hline & gross loss & 0.6 & 11.2 & 4.5 & 1.2 & 8.6 & & 0.1 \\
\hline & net change & 1.9 & 2.9 & 3.2 & 0.6 & 3.6 & & 0.0 \\
\hline & total change & 3.1 & 19.5 & 5.9 & 2.9 & 20.7 & & 0.2 \\
\hline & swap & 1.2 & 16.6 & 2.7 & 2.3 & 17.1 & & 0.2 \\
\hline
\end{tabular}

$\mathrm{AS}=$ artificial surface, $\mathrm{AL}=$ arable land, $\mathrm{BLF}=$ broad-leaved forest, $\mathrm{CF}=$ coniferous forest, $\mathrm{GL}=$ grassland, $\mathrm{PB}=$ peat bog, $\mathrm{WB}=$ water body

Source: Own 
There is an expansion of AS (new built-up areas) observable but not that high as it might have been expected. There is a shift of abandonment of old collection farms and the demand of land for newly developing industries and family houses, especially at the arterial roads and on the edges of settlements.
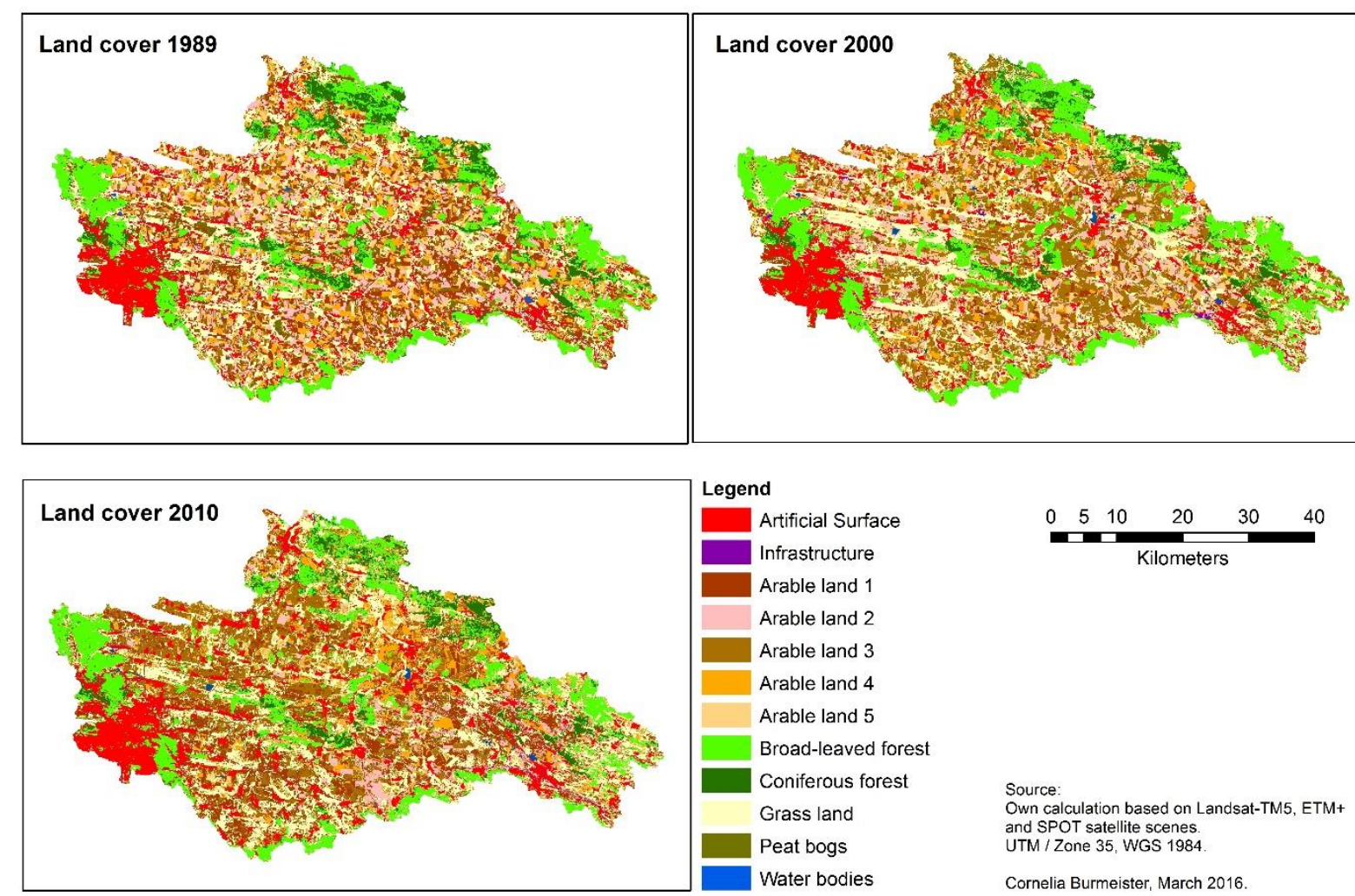

Own calculation based on Landsat-TM5, ETM+ and SPOT satellite scenes.
UTM / Zone 35, WGS 1984.

Cornelia Burmeister. March 2016.

Source: Own calculation, see lower right corner of Fig. 2.

Fig. 2: Land-cover classification results for the three time steps.

AL decreases from 1989 with $47.2 \%$ to 2010 with $44.3 \%$ in total. In contrast, GL increases by about almost 3\% from 1989 to 2010. This total number changes, as also the net change suggests, showing only low change rates $(0 . .2 .9 \%$ for AL as well as for GL with $0.7 \ldots 3.6 \%)$. However, the total change with 20\% (2000-2010) and swap present a high dynamic within these two classes, especially in space - as it can also be seen on the maps (cf. Fig. 2). That means that areas less suitable for agriculture are abandoned and GL with good properties as e.g. location or fertility are brought back into the agricultural cycle. This is also supported by Tab. 4 where a strong systematic change occurs between AL and GL. For the last decade 2000 to 2010 the gaining of GL from AL is stronger than in the decade before (3.0/5.4 to 1.8/3.3). Once again, this reflects on the one hand the concentration on suitable areas for cultivation and on the other hand the uncertainty which is caused by a non-functioning land market.

Other changes are seen around the settlements (500 m buffer). A lot of GL areas changed into field plots for subsistence farming after the break down of the socialistic system (which can be seen in the satellite scenes of 2000) and consequent a different parcelling to 1989 (also seen on Fig. 2). The change from GL to AL in the $500 \mathrm{~m}$ vicinity is higher than the change of AL into GL compensates. This is the reason for the increase of subsistence farming on close plots to the dwellings for the cultivation of food and fodder and also an indicator of poverty. The LC map of 1989 shows the intensive cultivation of AL with the huge amount of different 
field plots. After 2000, more importance was attached to big enterprises which cultivate the large fields now, and is visible in the changing of the field sizes and the connections of the fields (Fig. 2). Other systematic changes for the category AL are that it is not systematically transformed into BLF or CF and for the category GL, that it is not systematically changed into CF (Tab. 4).

Tab. 4: Systematic changes 1989 to 2000 , and 2000 to 2010

\begin{tabular}{|c|c|c|c|c|c|c|c|}
\hline \multirow{2}{*}{\multicolumn{2}{|c|}{ Categories 1989}} & \multicolumn{6}{|c|}{ Categories 2000} \\
\hline & & \multirow[t]{3}{*}{ AS } & \multirow{2}{*}{$\begin{array}{l}\mathrm{AL} \\
-1.2\end{array}$} & \multirow{2}{*}{$\begin{array}{l}\text { BLF } \\
-0.2\end{array}$} & \multirow{2}{*}{$\begin{array}{l}\mathrm{CF} \\
\quad 0.0\end{array}$} & \multirow{2}{*}{$\begin{array}{l}\text { GL } \\
-0.4\end{array}$} & \multirow{2}{*}{$\begin{array}{l}\text { WB } \\
0.0\end{array}$} \\
\hline AS & $\Delta \mathrm{O}-\mathrm{GG}$ & & & & & & \\
\hline & $\Delta \mathrm{O}-\mathrm{GL}$ & & -0.3 & -0.1 & 0.0 & 0.4 & 0.0 \\
\hline \multirow[t]{2}{*}{$\mathrm{AL}$} & $\Delta \mathrm{O}-\mathrm{GG}$ & -0.7 & & -1.3 & -0.3 & 1.8 & 0.0 \\
\hline & $\Delta \mathrm{O}-\mathrm{GL}$ & -1.6 & & -2.4 & -0.5 & 3.3 & 0.0 \\
\hline \multirow[t]{2}{*}{ BLF } & $\Delta \mathrm{O}-\mathrm{GG}$ & -0.2 & -2.0 & & 0.3 & -1.1 & 0.0 \\
\hline & $\Delta \mathrm{O}-\mathrm{GL}$ & -0.1 & -0.5 & & 0.4 & 0.2 & 0.0 \\
\hline \multirow[t]{2}{*}{$\mathrm{CF}$} & $\Delta \mathrm{O}-\mathrm{GG}$ & -0.1 & -0.6 & 1.4 & & -0.4 & 0.0 \\
\hline & $\Delta \mathrm{O}-\mathrm{GL}$ & -0.2 & -0.7 & 1.3 & & -0.3 & 0.0 \\
\hline \multirow[t]{2}{*}{ GL } & $\Delta \mathrm{O}-\mathrm{GG}$ & 1.1 & 3.2 & 0.1 & -0.2 & & 0.0 \\
\hline & $\Delta \mathrm{O}-\mathrm{GL}$ & 0.3 & 1.0 & -1.0 & -0.4 & & 0.0 \\
\hline \multirow[t]{2}{*}{ WB } & $\Delta \mathrm{O}-\mathrm{GG}$ & 0.0 & 0.0 & 0.0 & 0.0 & 0.0 & \\
\hline & $\Delta \mathrm{O}-\mathrm{GL}$ & 0.0 & 0.0 & 0.0 & 0.0 & 0.0 & \\
\hline
\end{tabular}

\begin{tabular}{|c|c|c|c|c|c|c|c|}
\hline \multirow{2}{*}{\multicolumn{2}{|c|}{ Categories 2000}} & \multicolumn{6}{|c|}{ Categories 2010} \\
\hline & & \multirow[t]{3}{*}{ AS } & \multirow{2}{*}{$\begin{array}{l}\text { AL } \\
-1.6\end{array}$} & \multirow{2}{*}{\begin{tabular}{|l|} 
BLF \\
-0.1
\end{tabular}} & \multirow{2}{*}{\begin{tabular}{|l|}
$\mathrm{CF}$ \\
-0.2
\end{tabular}} & \multirow{2}{*}{$\begin{array}{l}\text { GL } \\
-1.4\end{array}$} & \multirow{2}{*}{$\begin{array}{l}\text { WB } \\
0.0\end{array}$} \\
\hline AS & $\Delta \mathrm{O}-\mathrm{GG}$ & & & & & & \\
\hline & $\Delta \mathrm{O}-\mathrm{GL}$ & & -0.1 & 0.0 & 0.0 & 0.1 & 0.0 \\
\hline \multirow[t]{2}{*}{$\mathrm{AL}$} & $\Delta \mathrm{O}-\mathrm{GG}$ & -0.9 & & -0.4 & -0.5 & 3.0 & 0.1 \\
\hline & $\Delta \mathrm{O}-\mathrm{GL}$ & -2.2 & & -2.4 & -0.7 & 5.4 & 0.0 \\
\hline \multirow[t]{2}{*}{ BLF } & $\Delta \mathrm{O}-\mathrm{GG}$ & -0.2 & -1.4 & & 1.0 & -1.0 & 0.0 \\
\hline & $\Delta \mathrm{O}-\mathrm{GL}$ & -0.4 & -1.0 & & 1.0 & 0.4 & 0.0 \\
\hline \multirow[t]{2}{*}{$\mathrm{CF}$} & $\Delta \mathrm{O}-\mathrm{GG}$ & 0.0 & -0.2 & 0.2 & & -0.4 & 0.0 \\
\hline & $\Delta \mathrm{O}-\mathrm{GL}$ & -0.1 & -0.1 & 0.1 & & -0.1 & 0.0 \\
\hline \multirow[t]{2}{*}{ GL } & $\Delta \mathrm{O}-\mathrm{GG}$ & 1.1 & 3.1 & 0.2 & -0.3 & & 0.0 \\
\hline & $\Delta \mathrm{O}-\mathrm{GL}$ & 0.2 & 1.2 & -1.0 & -0.4 & & 0.0 \\
\hline \multirow[t]{2}{*}{ WB } & $\Delta \mathrm{O}-\mathrm{GG}$ & 0.0 & 0.0 & 0.0 & 0.0 & 0.0 & \\
\hline & $\Delta \mathrm{O}-\mathrm{GL}$ & 0.0 & 0.0 & 0.0 & 0.0 & 0.0 & \\
\hline
\end{tabular}

Abbreviation: $\Delta \mathrm{O}-\mathrm{GG}=$ delta observed - expected gross gain; $\Delta \mathrm{O}-\mathrm{GL}=$ delta observed - expected gross loss; $\mathrm{AS}=$ artificial surface; $\mathrm{AL}=$ arable land; $\mathrm{BLF}=$ broad-leaved forest; $\mathrm{CF}=$ coniferous forest; $\mathrm{GL}=$ grassland $\mathrm{PB}=$ peat bog; $\mathrm{WB}=$ water body.

Blue-colored cells show a negative systematic change, a change is impeded.

Green-colored cells show a positive systematic change, the LC category gains from the other.

Source: Own 
The classes BLF and CF decline over the 21 years of the study period (see Tab. 3). The forest class BLF depicts a gain higher than a loss in the period from 1989 to 2000 . After the next decade, the gross loss for BLF is higher than the gross gain but the swap is with 2.7 the same for both decades. For the category CF, it is the other way round. The swap of $3 \%$ for CF (two thirds of the whole LC class) also shows a high dynamic for the forest classes. The systematic change (Tab. 4) depicts a systematic interchange of the forest classes and that it is impeded by BLF changes in AS and AL. The only difference that occurs between the time periods is that the exchange of the forest classes is more one-sided to CF.

\subsection{Accuracy Assessment}

Accuracy assessment is performed using statistical measures which are based on the calculation of the error matrix that consists of the correct and misclassified pixels of the LC classes. The classification algorithm shows different accuracy results for the three time steps: 1989 displays an overall accuracy of $84.5 \%$ with an overall kappa of $0.8,2000$ has an overall accuracy of $92 \%$ with an overall kappa of 0.89 , and 2010 demonstrates overall accuracy of $92.6 \%$ with an overall kappa of 0.89 .

\section{Conclusion}

The paper shows how an enhanced statistical analysis of past land-cover developments can help to identify the relevant changes. Although the Maximum Likelihood classifier is a straight forward approach, it has delivered good results. The Landsat and Spot satellite series are able to provide long time coverage of a single service. By means of them, the selection of inner-annual time steps of the satellite images in one year was possible even for 1989. The inner-annual scenes support the differentiation between arable land and grassland and bare arable land and artificial surface a lot.

The enhanced analysis of the LC change shows main change trajectories:

- the high interchange of arable land and grassland due to location and fertility issues which is stronger in 2000 to 2010 for grassland

- the interchange of the forest kinds

- the protection of arable land and broad-leaved forest /coniferous forest because it is not systematically changed into artificial surface. This is different to developments in other countries, e.g. Germany, where new built-up areas (category artificial surface) develop mostly on arable land.

\section{Acknowledgements}

This paper is based on work carried out under the research project "IWAS - International Water Alliance Saxony" (grant 02WM1028) which has been funded by the German Federal Ministry of Education and Research (BMBF). The authors would also like to thank Sirius for providing SPOT satellite data for this research.

\section{Literature}

[1] LAMBIN, E. F. et al.: The Causes of Land-Use and Land-Cover Change: Moving beyond the Myths, In: Global Environmental Change. 2001, Volume 11, Issue 4, pp. 261-69. DOI: 10.1016/S0959-3780(01)00007-3.

[2] FAO and UNEP: The Future of Our Land. Facing the Challenge. 1999. 
[3] GEIST, H.; McCONNELL, W.; LAMBIN, E. F.; MORAN, E.; ALVES, D.; RUDEL, T.: Causes and Trajectories of Land-Use/Cover Change. Chapter 3 in: Land-Use and Land-Cover Change. Springer Berlin Heidelberg, Berlin, Heidelberg 2006. pp. 41-70. DOI: $10.1007 / 3-540-32202-7 \_3$.

[4] PONTIUS, R. G.; SHUSAS, E.; McEACHERN, M.: Detecting important categorical land changes while accounting for persistence. In: Agriculture, Ecosystems \& Environment. 2004. Vol. 101, pp. 251-68.

[5] MANANDHAR, R.; ODEH, I. O. A.; PONTIUS, R. G.: Analysis of twenty years of categorical land transitions in the Lower Hunter of New South Wales, Australia. In: Agriculture, Ecosystems \& Environment. 2010, Vol. 135, pp. 336-46.

[6] TAKADA, T.; MIYAMOTO, A.; HASEGAWA, S. F.: Derivation of a yearly transition probability matrix for land-use dynamics and its applications. In: Landscape Ecol. 2010, Volume 25, pp. 561-72.

[7] BRAIMOH, A. K.: Random and systematic land-cover transitions in northern Ghana. In: Agriculture, Ecosystems \& Environment. 2006, Volume 113, pp. 254-63.

[8] SEEGERT, J.; BERENDONK, T. U.; BERNHOFER, C.; BLUMENSAAT, F.; DOMBROWSKY, I.; FUEHNER, C.; GRUNDMANN, J.; HAGEMANN, N.; KALBACHER, T.; KOPINKE, F.-D.; LIEDL, R.; LEIDEL, M.; LORZ, C.; MAKESCHIN, F.; MARKOVA, D.; NIEMANN, S.; RÖSTEL, G.; SCHANZE, J.; SCHEIFHACKEN, N.; SCHUETZE, N.; SIEBERT, C.; STEFAN, C. B.; STREHLITZ, B.; TEUTSCH, G.; WEIGELT, C.; WEIß, H.; KOLDITZ, O.; BORCHARDT, D.; KREBS, P.: Integrated water resources management under different hydrological, climatic and socio-economic conditions: results and lessons learned from a transdisciplinary IWRM project IWAS. In: Environmental Earth Sciences. 2014, Volume 72, Bd. 12, pp. 4677-4687.

[9] SCHANZE, J.; TRÜMPER, J.; BURMEISTER, C.; PAVLIK, D.; KRUHLOV, I.: A methodology for dealing with regional change in integrated water resources management. Environmental Earth Science. 2012, Volume 65, pp. 1405-14.

[10] TAVARES WAHREN, F.; HELM, B.; SCHUMACHER, F.; PLUNTKE, T.; FEGER, K-H.; SCHWÄRZEL, K.: A Modeling Framework to Assess Water and Nitrate Balances in the Western Bug River Basin, Ukraine, In: Advanced Geosciences. 2012, Volume 32, pp. 85-92. DOI: 10.5194/adgeo-32-85-2012.

[11] PLUNTKE, T.; PAVLIK, D.; BERNHOFER, C.: Reducing Uncertainty in Hydrological Modelling in a Data Sparse Region, In: Environmental Earth Sciences. 2014, Volume 72, Issue 12, pp 4801-4816. DOI: 10.1007/s12665-014-3252-3.

[12] Lviv. In: Wikipedia. [encyclopedia online]. Wikimedia Foundation Inc. [accessed 201603-15]. Available from http://de.wikipedia.org/w/index.php?title=Lemberg\&oldid=106446515

[13] ERTEL, A-M.; LUPO, A.; SCHEIFHACKEN, N.; BODNARCHUK, T.; MANTUROVA, O.; BERENDONK, T.; PETZOLDT, T.: Heavy load and high potential: anthropogenic pressures and their impacts on the water quality along a lowland river (Western Bug, Ukraine). In: Environmental Earth Sciences. 2011, pp. 115 .

[14] GOROBETS, A.: An independent Ukraine: Sustainable or unsustainable development? In: Communist and Post-Communist Studies. 2008, Volume 41, pp. 93-103. 
[15] KUZIO, T.: Political Culture and Democracy Ukraine as an Immobile State. In: East European Politics and Societies. 2011, Volume 25, pp. 88-113.

[16] RIABCHUK, M.: Ukraine's 'muddling through': National identity and postcommunist transition. In: Communist and Post-Communist Studies. 2012, Volume 45, Issues 3-4, pp. 439-446. DOI: 10.1016/j.postcomstud.2012.06.007.

[17] BEREND, I. T.: Social shock in transforming Central and Eastern Europe. In: Communist and Post-Communist Studies. 2007, Volume 40, Issue 3, pp. 269-280. DOI: 10.1016/j.postcomstud.2007.06.007.

[18] DYKUNSKYY, I.: Das Wichtigste aus dem verabschiedeten Gesetz: Über das staatliche Bodenkataster? 15.09.2011, [accessed 2016-03-16]. Available from WWW: http://ukraine-nachrichten.de/wichtigste-verabschiedeten-gesetz-\%C3\%BCberstaatliche-bodenkataster_3276_pressemitteilungen\$

[19] ZATURJAN, M.: Parlament unterstützt Verlängerung des Moratoriums für den Verkauf von Ackerland. Kommersant-Ukraine 2009, [accessed 2016-03-16]. Available from WWW:

http://ukraine-nachrichten.de/parlament-unterst\%C3\%BCtztverl\%C3\%A4ngerung-moratoriums-verkauf-ackerland_2036

[20] GRIFFITHS, P.: Utilizing the Depth of the Landsat Archive to Reconstruct Recent Land Change in the Carpathian Ecoregion. 2013, Dissertation. Humboldt-Universität zu Berlin. Available from WWW: http://edoc.hu-berlin.de/dissertationen/griffiths-patrick2013-09-27/METADATA/abstract.php?id=40331

Dipl. Geogr. Cornelia Burmeister; Professor Jochen Schanze, Ph.D. 


\section{RETROSPEKTIVNÍ ANALÝZA SYSTEMATICKÝCH ZMĚN ZEMSKÉHO POVRCHU V POVODÍ HORNÍHO ZÁPADNÍHO BUGU NA UKRAJINĚ}

Článek popisuje př́stup a empirické výsledky systematických změn $\mathrm{v}$ povodí horního Západního Bugu na Ukrajině. Z teledat satelitu Landsat a SPOT je určen zemský povrch v období 1989, 2000 a 2010. Každý časový úsek je pritom zastoupen třemi obrázky z různých ročních období s cílem integrovat vývoj vegetace a opravit klasifikaci pomocí metody maximální věrohodnosti. Jako výsledek bylo detektováno celkem šest tř́d: zastavěná plocha (městská), listnatý les, jehličnatý les, zemědělská půda, zeleň a vodstvo. Po učení povrchu $\mathrm{v}$ jednotlivých časových úsecích jsou zkoumány změny vzniklé za poslední dvě desetiletí. Pozorovaný pokles a růst je statisticky analyzován, aby mohly být stanoveny systematické a náhodné změny zemského povrchu ve zkoumané oblasti. Výsledky ukazují, že orná půda není přeměněna na zastavěné plochy. Orná půda se mění $\mathrm{v}$ travnaté porosty a naopak. Tato systematická změna je velmi silná. V klasifikaci lesních porostů jde především o vzájemnou záměnu, prričemž více dochází $\mathrm{k}$ přeměně lesů jehličnatých na listnaté.

\section{RETROSPEKTIVE ANALYSE DES SYSTEMATISCHEN LANDBEDECKUNGSWANDELS IM EINZUGSGEBIET DES OBEREN WESTLICHEN BUG, UKRAINE}

Der Artikel zeigt die Herangehensweise und empirische Ergebnisse des systematischen Landbedeckungswandels im Einzugsgebiet des oberen Westlichen Bugs in der Ukraine. Aus Fernerkundungsdaten der Satelliten Landsat und SPOT wird die Landbedeckung für die Zeitschritte 1989, 2000 und 2010 bestimmt. Dabei wird jeder einzelne Zeitschritt mithilfe von drei innerjährlichen Bildern repräsentiert, um die Vegetationsentwicklung zu berücksichtigen und die Klassifikation mit dem Maximum Likelihood Classificator zu verbessern. Als Ergebnis wurden sechs Klassen detektiert: versiegelte bebaute Fläche (städtisch), Laubwald, Nadelwald, Ackerfläche, Grünland und Wasser. Nach der Ermittlung der Landbedeckung in den einzelnen Zeitschritten wird der Wandel über die zwei Jahrzehnte untersucht. Der beobachtete Rückgang und Zuwachs wird statistisch analysiert, um den systematischen und zufälligen Landbedeckungswandel für das Untersuchungsgebiet zu identifizieren. Die Ergebnisse zeigen, dass Ackerfläche nicht in bebaute Fläche umgewandelt wird. Ackerfläche geht in Grünland über und umgekehrt. Dieser systematische Wandel ist sehr stark ausgeprägt. In den beiden Waldklassen gibt es hauptsächlich einen wechselseitige Nutzungsänderung, wobei in den letzten zehn Jahren mehr Nadelwald in Laubwald umgewandelt wird.

\section{RETROSPEKTYWNA ANALIZA UKIERUNKOWANYCH ZMIAN POKRYCIA TERENU W DORZECZU GÓRNEGO ZACHODNIEGO BUGU, UKRAINA}

$\mathrm{W}$ artykule przedstawiono podejście do tematyki ukierunkowanych zmian pokrycia terenu oraz empiryczne wyniki badań przeprowadzonych w zlewni górnego Zachodniego Bugu na Ukrainie. Pokrycie terenu zostało określone przy pomocy danych Teledetekcji Landsat i SPOT dla lat 1989, 2000 i 2010. Każdy krok czasowy reprezentowany jest przy pomocy trzech zdjęć satelitarnych służących uchwyceniu rozwoju roślinności oraz poprawie klasyfikacji metodą nawiększej wiarygodności. W rezultacie wyodrębniono sześć klas: teren zabudowany (miejski), las liściasty, las iglasty, grunty orne, łąki oraz wody. Na podstawie badań pokrycia terenu dla poszczególnych etapów czasowych określono zmiany w nim zachodzące na przestrzeni dwóch dekad. Obserwowany spadek i wzrost analizowanych klas poddany został statystycznej analizie $w$ celu identyfikacji ukierunkowanych i losowych zmian pokrycia terenu na badanym obszarze. Wyniki pokazują, że grunty orne nie zostają przekształcane w tereny zabudowane. Grunty orne zamienia się w łąki i odwrotnie. 